
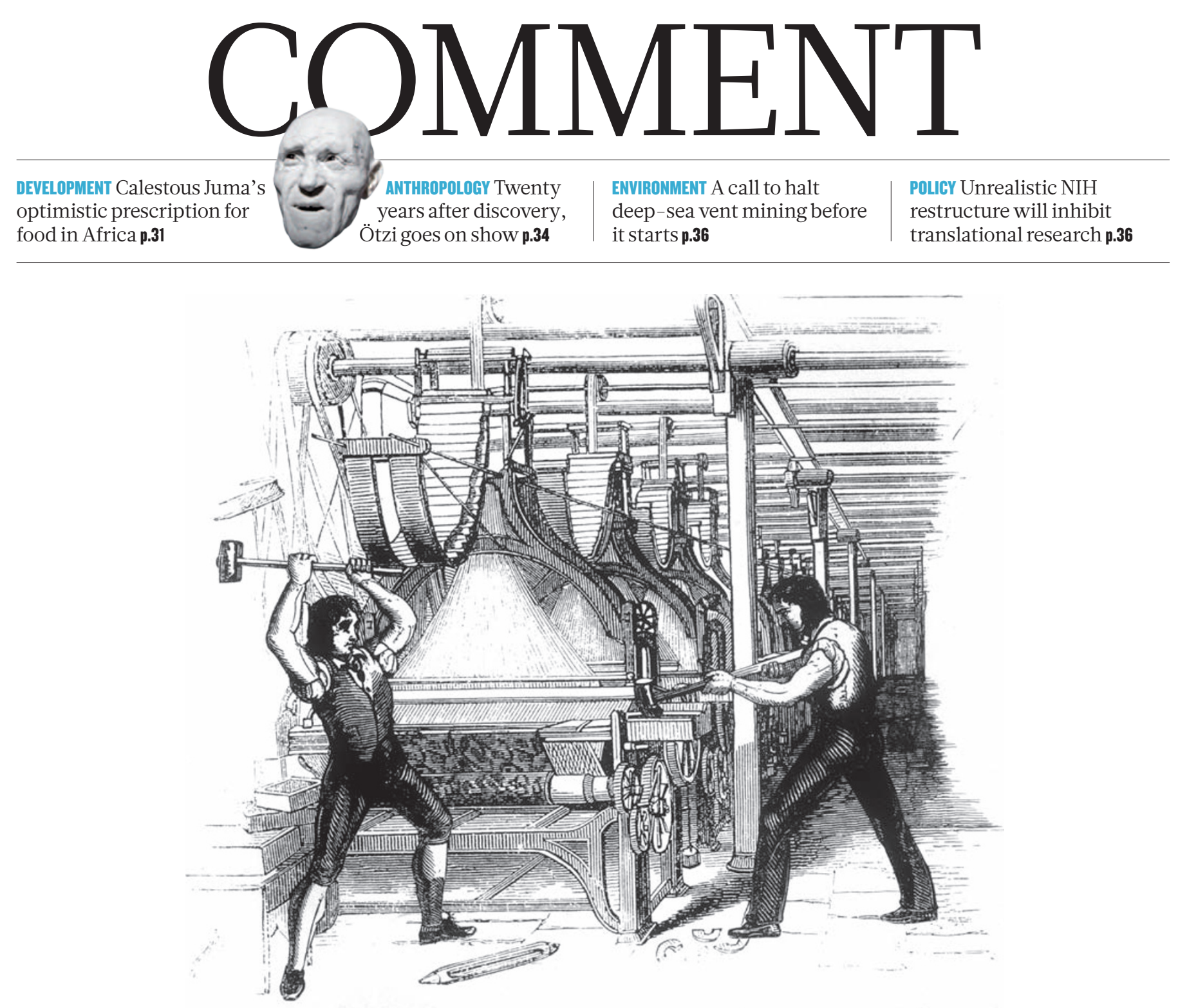

A nineteenth-century engraving of machine-breakers attacking machinery in a textile factory.

\title{
In praise of Luddism
}

\section{Two centuries on from the Luddite insurrection, David Edgerton celebrates today's most important opponents to new ideas, inventions and innovations: scientists.}

\section{I}

n March 1811, machine-breakers struck in the centre of England. They were not the first or the last, but they started what became known as the Luddite outrages or insurrection. The targets were employers and their machines - stocking-makers and their knitting frames at first, later other textile manufacturers and machines. The breakers were hand-knitters whose livelihood was threatened. The name came from General or King Ludd, the leader the Luddites invented as a signatory to proclamations.

Since then, especially in the late twentieth century, a Luddite has been someone opposed to progress, especially to science and technology. Nowadays, it is a generalized term of unthinking abuse designed to crush any criticism.

In fact, opposition to most new ideas, inventions and innovations is essential for progress. Most grant applications and scientific papers are rejected; most inventions have to be rejected if there is to be enough time and money to develop any at all. Scientists have had a crucial role in this opposition - they led the charge against new gadget mania during the Second World War, and afterwards.

If by 'Luddism' we mean, as was the case in 1811, opposition to specific novelties for particular reasons, as opposed to novelty in general, then Luddism is indispensable and scientists should cultivate their important, and venerable, role as its most rigorous practitioners.

It is not sufficiently recognized that creation, scientific or otherwise, is a tragic business. Most inventions meet nothing but indifference, even from experts. Patents are little more than a melancholy archive of failure. Most ideas of every sort are rejected, as would be clear if there was a repository for abandoned drafts, rejected manuscripts, unperformed plays and unfilmed treatments. The reason is not hostility to novelty. 
On the contrary, most new ideas and products must be rejected because there are so many of them. In the rich world, some institutions and individuals have been so fecund with inventions that not even all the good ones could be used: there have been many processes to make, say, synthetic ammonia, or take colour photographs, but only a few are used. The point is not whether we reject, but how we do it, and why.

Scientific Luddism, however, doesn't even acknowledge its own existence. How could it, in a world in which science is held to be about creativity, innovation, the future, ideas, inventions and spin-outs? Party poopers are not welcome.

\section{WAR ON WASTE}

Science has a long and distinguished history of Luddism. In the early eighteenth century, some natural philosophers — such as the Royal Society's Jean Desaguliers - worked to discredit many projects and doubtless saved fortunes from being invested in perpetual motion machines. For example, with the rise of science-based industry in the late nineteenth century, chemicals companies employed scientists not just to control processes, or to create, but also to assess, and thus usually reject, inventions. Within government, scientists were used to sift through the thousands of ideas for potentially war-winning gadgets that were received from patriotic inventors in both great wars of the twentieth century.

In the Second World War, British scientists were actively involved in opposing new ideas for weapons. Surely there were enough Luddites in government and the armed forces in Britain that no help was needed from scientists? That certainly was the public view of many scientists who railed against administrators and politicians educated in the classics and history. The reality was very different: the British political and military elite (supported by many scientists of course) was addicted to new machines, to machines that would transform war and allow a great scientific nation to triumph over hordes of continental conscripts. Neville

Chamberlain, prime minister between May 1937 and May 1940, who had a university education in science, was one such neophile, but in this as in so much else, he was overshadowed by his successor Winston Churchill.

Churchill was a noted enthusiast for machines and an inventor himself. His close personal adviser on matters scientific, technical and economic, was an Oxford professor, the physicist Frederick Lindemann, easily the most influential academic or scientist to have served in government. Their response to the crisis of 1940 - the fall of Norway, the evacuation of Denmark and the fall of France - involved a call for more radical weapons. Between them they encouraged all sorts of new gadgets: aerial mines to bring down bombers, jet engines, the atomic bomb, anti-aircraft rockets, anti-tank devices of many kinds. Their enthusiasm was boundless, their progress-chasing relentless.

Among the Luddites were the physiologist Archibald V. Hill, the chemist Henry Tizard and the physicist Patrick Blackett, all experienced scientific advisers. Hill was elected by the graduates of the University of Cambridge to one of their two Parliamentary seats (a system abolished in the late 1940s) and was the only scientific Nobel laureate ever to sit in the Commons. He was a conservative, but one of Churchill's strongest opponents. Blackett was a socialist, who won his Nobel prize after the war. Tizard was the dean of scientific advisers, and associated with the most technically progressive part of government since the First World War - the air force.

All three men turned against the inventors and the prime minister who so actively supported them. As Hill complained to Parliament in February 1942: "There have been far too many ill-considered inventions, devices, and ideas put across, by persons with influence in high places, against the best technical advice... They have cost the country vast sums of money and a corresponding effort in development and production, to the detriment of profitable expenditure of labour and materials elsewhere."

We know from Hill's papers that he thought the greatest waste of money was the anti-aircraft rocket programme dating from the 1930s. He estimated that this giant effort cost the equivalent of between 3 and 16 battleships, or the same number of very large factories, and consumed three or four times more cordite than used to fire the same number of conventional anti-aircraft shells. He called it a "most infernal waste of time, effort, manpower and material". By June 1941, the government was demanding production of 9 million rockets a year, despite the fact that they barely worked. They are now all but forgotten. In fact, production never exceeded 2.5 million, and was saved by an unexpected new use for the rockets as ship- and tank-busters.

Blackett, who headed operational research for the navy, engaged in a general critique of the pursuit of novelty. Writing in December 1941, in a paper setting out the principles of operational research, he criticized the call for 'New weapons for old', as a form of "escapism". Too little effort was going into "the proper use of what we have got", he wrote. Changing tactics could be more effective than changing weapons ${ }^{1}$. He and Tizard wanted to redeploy scientists from research and development to "improve the operational efficiency of equipment and methods now in use". Both men also opposed Britain building an atomic bomb, on the grounds that it was likely to take longer and cost more than promised. In this they were proved correct - there was no bomb until the US one of 1945, and far from being cheaper than conventional explosive, it was the most expensive ever made. The US bomb took at least 2 years longer, and cost 50 times more, than the British bomb was meant to.

Being a scientific Luddite was not easy. Charles Goodeve, who had been the Admiralty's senior scientist during the Second World War, recalled that "the voices of reason" who opposed, on the grounds of cost, the extraordinary wartime scheme to build a gigantic aircraft carrier out of ice (codename Habakkuk) were "shouted down by cries of 'obstruction" in the internal deliberations of government. Goodeve estimated (although this is certainly an exaggeration) that Habakkuk was the most serious misallocation of Allied effort of any wartime invention ${ }^{2}$. It was supported by scientists of distinction, most notably the socialist crystallographer J. D. Bernal, but fortunately was not pursued beyond the experimental stage.

The Second World War has been treated as a moment of triumph for British science, and this is associated with a small range of wellknown devices - radar, jet engines, penicillin, the Mulberry artificial harbour, the Pipe Line Under The Ocean (PLUTO) and sometimes the Habakkuk. Of these, only radar made a definite positive contribution to the war. Most of the rest were either irrelevant to it, or of marginal importance. British jet engines made no impact, nor did the atomic bomb, which marked rather than caused the end of the war. The two Mulberry harbours towed to the Normandy beaches, although much celebrated, contributed less than propaganda implies then and since. The Americans managed perfectly well after the Mulberry built for them was destroyed in a storm before it was even finished. The PLUTO, which took petrol across the English Channel, although built at great expense, was, as US Luddites had suggested, quite unnecessary and, furthermore, worked very badly.
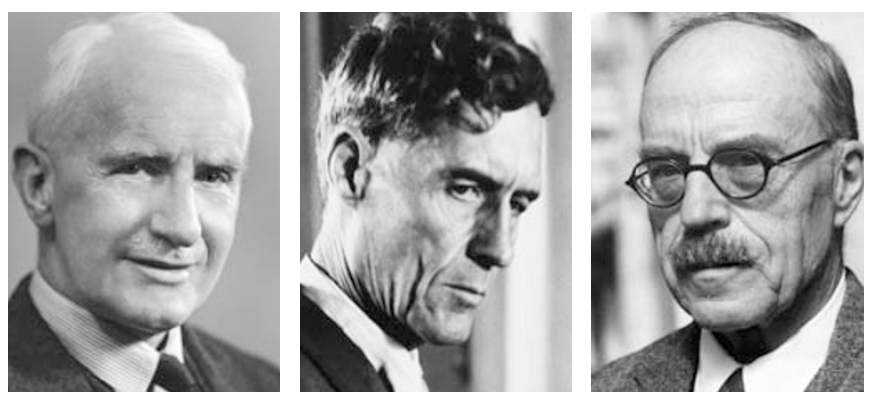

Churchill's Luddites: Archibald V. Hill, Patrick Blackett and Henry Tizard. 
